\title{
Preparation and Some Properties of Chitosan Bound Enzymes
}

\author{
Takafumi KasumI, Masatake TsuJI, ${ }^{*}$ Kiyoshi Hayashi \\ and Nobuzo Tsumura \\ National Food Research Institute, Ministry of Agriculture and Forestry, Koto-ku, Tokyo \\ Received February 9, 1977
}

\begin{abstract}
An immobilization method using chitosan prepared from chitin as an insoluble carrier was investigated. Glucose isomerase, urease, glucamylase, trypsin and glucose oxidase were attached to chitosan by the aid of water soluble carbodiimide. Their activity yields were as follows; glucose isomerase $32 \%$, urease $44 \%$, glucamylase $8 \%$, trypsin $10 \%$, glucose oxidase $37 \%$.

Immobilized glucose isomerase showed no significant changes in optimal temperature and heat stability. But $\mathrm{pH}$ optimum of reaction and $\mathrm{pH}$ stability range were somewhat lowered. The inhibitory effects of bivalent metal ions were considerably reduced by immobilization and similar tendency was observed for buffer reagents such as Tris or veronal. Immobilized glucose isomerase was inhibited by $8 \mathrm{~m}$ urea or $6 \mathrm{M}$ guanidine hydrochloride in nearly the same way as free enzyme. With SDS, cysteine or mercaptoethanol free glucose isomerase was scarcely affected by these reagents, while immobilized enzyme considerably suffered to a loss of its activity.
\end{abstract}

Recently, immobilized enzymes have been the subject of much increased interest because they have more potential activity than free enzymes. Practically, their insoluble properties make it possible to operate an enzyme engineering process continuously in place of batch process. They can also be applied to the fields of medicine, food and analytical chemistry. In research field, they may serve as model system for natural enzyme bound to in vivo membrane. A number of papers ${ }^{1 \sim 33}$ have been reported as to preparation and application of immobilized enzymes.

Glucose isomerase is one of the most important enzymes in industrial aspect and its demand is increasing year by year. Various methods $^{4 \sim 10)}$ of immobilization for this enzyme have been described. In previous papers ${ }^{11,12}$ ) we have shown the preparation of immobilized glucose isomerase derived from a species of Streptomyces by entrappment in cross linked gels. Utilization of chitosan for immobilization, which is deacetylated polysaccharide prepared from chitin, has also been examined. The chitosan in the dissolved state is strong

* Present address: Central Laboratory, Gôdô Shusei Co., Ltd., Matsudo, Chiba. flocculant because of its polycationic characteristics. Cells of Streptomyces containing glucose isomerase are aggregated effectively by the treatment with chitosan. Therefore, whole cell aggregation method ${ }^{13,14}$ for the immobilization of glucose isomerase has been carried out.

This article deals with a method of immobilization for several enzymes including glucose isomerase through binding between chitosan and enzymes by the catalytic reaction of water soluble carbodiimide; 1-cyclohexyl-3-(2-morpholinoethyl) carbodiimide metho- $p$-toluenesulfonate. Besides glucose isomerase, urease, glucamylase, trypsin and glucose oxidase were tried for immobilization.

\section{MATERIALS}

Glucose isomerase. Cell of Streptomyces sp. cultured and harvested according to the method shown in the previous paper ${ }^{15)}$ was crushed by the disintegrator, Dyno-Mill (Willy A. Bachofen, Switzerland), and centrifuged at $8000 \mathrm{rpm}$ to remove the cell debris. Supernatant was salted out with ammonium sulfate in cooling at around $0^{\circ} \mathrm{C}$. A fraction precipitated between $0.3 \sim 0.5$ saturation was dissolved and dialyzed against $0.05 \mathrm{M}$ sodium phosphate buffer, $\mathrm{pH} 7.5$. Dialyzate was applied to DEAE-Sephadex column 
and gradient elution with $\mathrm{KCl}$ was carried out. Active fractions of effluent were collected and dialyzed against the same buffer for $24 \mathrm{hr}$. Purification by DEAESephadex column was repeated until glucose isomerase became a single band in polyacrylamide gel electrophoresis.

Other enzymes. Urease and glucose oxidase were purchased from Tōkyō Kasei Kōgyō Co., Ltd. Glucamylse (mixed with starch, free from $\alpha$-amylase) was obtained by the courtesy of Amano Seiyaku Co., Ltd. and trypsin was purchased from Merck.

Chitosan. Chitosan, which was prepared from chitin through deacetylation by boiling with $40 \%$ $\mathrm{NaOH}$ for $2 \mathrm{hr}$ and washing with water and then dried for $12 \sim 16 \mathrm{hr}$ at $100^{\circ} \mathrm{C}$, was obtained from Gōdō Shusei Co., Ltd. Degree of deacetylation was estimated to be more than $50 \%$ according to colloid titration method and viscosity of $0.5 \%$ solution of the chitosan in $0.5 \%$ acetic acid was about 53 centipoise according to the determination by Cannon-Fenske type capillary method. One gram of chitosan was dispersed in $80 \mathrm{ml}$ of $0.5 \%$ acetic acid and dissolved. After adjustment of $\mathrm{pH}$ value to about 6 with $5 \mathrm{~N}$ $\mathrm{NaOH}$, chitosan solution was filled up to $100 \mathrm{ml}$ with water and filtered to remove the insoluble materials.

Water soluble carbodiimide. 1-Cyclohexyl-3-(2morpholinoethyl)carbodiimide metho-p-toluenesulfonate (abbr. CMC, Aldrich Chemical Co., Inc.) was used.

\section{METHOD}

\section{Preparation of chitosan bound enzymes}

Five $\mathrm{ml}$ of chitosan solution was taken in $2.0 \mathrm{~cm}$ dia. $\times 10 \mathrm{~cm}$ test tube and $60 \mathrm{mg}$ of $\mathrm{CMC}$ was mixed in it. Subsequently $1 \sim 2 \mathrm{ml}$ of glucose isomerase solution was added. After substitution of the air in head space of tube with nitrogen gas, the vessel was sealed with parafilm and kept at room temperature for several hours with gentle stirring. Then, chitosanenzyme was precipitated by raising $\mathrm{pH}$ to $8 \sim 9$ with $0.2 \mathrm{M}$ ammonium buffer ( $\mathrm{pH} 10.0$ ). Leaving for a minute, the preparation was separated by filtration and washed several times with water. Immobilized urease and glucamylase were prepared in the same manner as glucose isomerase. In the case of trypsin, however, a chitosan solution was adjusted to $\mathrm{pH} 4.0$ because trypsin was apt to lose its activity at $\mathrm{pH}$ over 5 by autolysis. While, glucose oxidase was made inactive in alkaline $\mathrm{pH}$ (over 8 ), so chitosan bound glucose oxidase was precipitated carefully by ammonium buffer at $\mathrm{pH}$ below 8 .

\section{Assay method}

a) Glucose isomerase. The reaction mixture was composed of $0.8 \mathrm{M}$ glucose, $0.01 \mathrm{M} \mathrm{MgSO}_{4}, 0.05 \mathrm{M}$ sodium phosphate buffer ( $\mathrm{pH}$ 7.5) and enzyme, unless otherwise remarked (in a final concentration). Total volume was $2 \mathrm{ml}$. After incubation for $30 \mathrm{~min}$ at $60^{\circ} \mathrm{C}$, fructose formed was determined colorimetrically by the cysteine-carbazole-sulfuric acid method. ${ }^{16)}$ An arbitrary unit of enzyme was defined as the amount of enzyme which produce $1 \mathrm{mg}$ of fructose under this condition. Specific activity of enzyme used was 60.2 unit/mg.

b) Urease. Colorimetric method of Van Slyke et $a .^{17)}$ was employed. Enzyme activity was expressed by Sumner unit. Specific activity of enzyme used was 0.0263 unit/mg.

c) Glucamylase. Five grams of enzyme preparation was washed several times with $0.02 \mathrm{M}$ phosphate buffer ( $\mathrm{pH} 7.0$ ). Washings were collected and filled up to $50 \mathrm{ml}$. Enzyme activity was determined by the method of Okazaki et al. ${ }^{18)}$ with a little modification as follows: One $\mathrm{ml}$ of enzyme solution prepared as above described was added to the mixture of $2 \mathrm{ml}$ of $1 \%$ soluble starch and $1 \mathrm{ml}$ of $0.2 \mathrm{M}$ phosphate buffer (pH 6.0), and allowed to react for $10 \mathrm{~min}$ at $40^{\circ} \mathrm{C}$. Immobilized glucamylase liquefied once under this condition. The reaction was stopped by the addition of $0.5 \mathrm{M}$ perchloric acid and chitosan-enzyme was solidified again by neutralization of $\mathrm{pH}$ of the mixture with $0.25 \mathrm{~N} \mathrm{NaOH}$, and then removed by filtration. Reducing sugar liberated in filtrate was determined by the method of Somogyi et al. ${ }^{1 \theta)}$ One unit of enzyme was defined as the activity which produce a reducing power equivalent to $1 \mu \mathrm{g}$ of glucose. The enzyme had specific activity of $448 \mathrm{unit} / \mathrm{ml}$.

d) Trypsin. Determination of enzyme activity was carried out according to Hagihara's method ${ }^{20)}$ with a little modification as follows: Two $\mathrm{ml}$ of enzyme solution was mixed with $2 \mathrm{ml}$ of $2 \%$ casein solution ( $\mathrm{pH} \mathrm{7.5).} \mathrm{After} \mathrm{incubation} \mathrm{for} 10 \mathrm{~min}$ at $40^{\circ} \mathrm{C}$, reaction was stopped in boiling water for $3 \mathrm{~min}$ and subsequently immobilized enzyme was removed by filtration. To $2 \mathrm{ml}$ of filtrate was added $2 \mathrm{ml}$ of protein precipitation reagent (mixture of $0.11 \mathrm{M}$ $\mathrm{CCl}_{3} \mathrm{COOH}, 0.22 \mathrm{M} \mathrm{CH}_{3} \mathrm{COONa}$ and $0.33 \mathrm{M} \mathrm{CH}_{8}$ $\mathrm{COOH}$ ) and kept for $20 \mathrm{~min}$ and then filtered. The soluble product was estimated by the colorimetric method using Folin Ciocalteu reagent. ${ }^{21}$ ) One unit of enzyme was defined as the activity which gave absorbance of 0.01 at $670 \mathrm{~nm}$. Specific activity of the enzyme used was $384 \mathrm{unit} / \mathrm{mg}$.

e) Glucose oxidase. To the mixture of $1 \mathrm{ml}$ of $0.5 \%$ glucose in $0.05 \mathrm{M}$ phosphate buffer (pH 6.0) and $1 \mathrm{ml}$ of peroxidase- $o$-dianisidine was added $2 \mathrm{ml}$ of enzyme solution and kept at $30^{\circ} \mathrm{C}$ for $5 \mathrm{~min}$. The reaction was stopped with 1 drop of $4 \mathrm{~N} \mathrm{HCl}$. Developped color was estimated spectrophotometrically at $460 \mathrm{~nm}$. One unit of enzyme was defined as the activity which gave absorbance equivalent to $1 \mu \mathrm{g} /$ 
$\mathrm{ml}$ of glucose. Specific activity of the enzyme used was 255 unit/mg.

\section{RESULTS}

1. Effect of CMC on the activity of glucose isomerase

The enzyme activity was supposed to be affected with CMC by the modification of free carboxyl groups or other structures in the protein. Therefore effect of $\mathrm{CMC}$ on the activity of free (mobile) glucose isomerase was investigated. As shown in Fig. 1, the activity was gradually reduced to $70 \%$ of initial value after incubation with $1 \% \mathrm{CMC}$ for $6 \mathrm{hr}$. But in the presence of excess D-glucosamine, a monomer sugar of chitosan, glucose isomerase showed little loss in activity. From these result it was expected that the inhibition of enzyme activity by CMC treatment would also be small in the presence of chitosan.

Disc gel electrophoretic pattern of CMC treated glucose isomerase is shown in Fig. 2. Delay of migration and broadening of the band were observed corresponding to incubation time. These effects were probably due to the

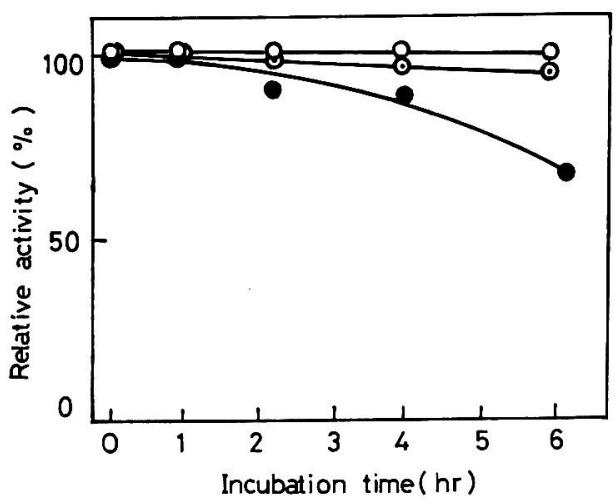

Fig. 1. Effect of CMC on the Activity of Glucose Isomerase.

Enzyme was incubated with $1 \% \mathrm{CMC}$ at room temperature and then, remaining activity was estimated. Composition of incubation mixture was as follows: 0 - O control, $1 \mathrm{ml}$ of glucose isomerase $(0.97 \mathrm{mg})$ and $5 \mathrm{ml}$ of $0.02 \mathrm{M}$ phosphate buffer $(\mathrm{pH} 6.0)$, $60 \mathrm{mg}$ of CMC was added to the control, $\odot-\odot 60 \mathrm{mg}$ of $\mathrm{CMC}$ and $60 \mathrm{mg}$ of $\mathrm{D}$-glucosamine $\cdot \mathrm{HCl}$ were added to the control.

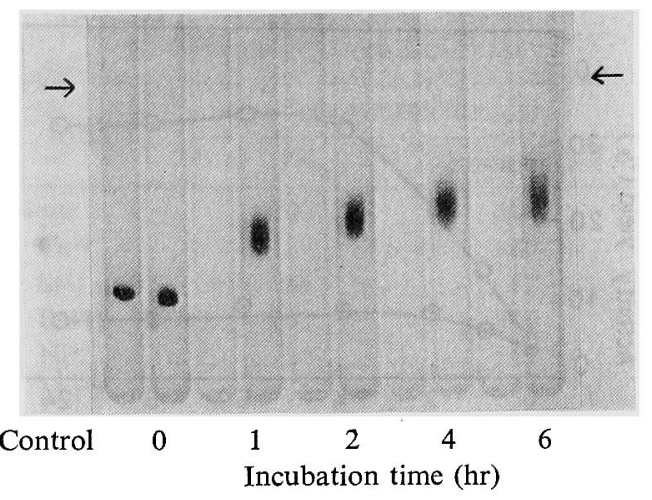

FIG. 2. Disc Electrophoresis of CMC Treated Glucose Isomerase on Polyacrylamide Gels $(7.5 \%, \mathrm{pH}$ 9.4).

Enzyme was incubated with $1 \%$ of $\mathrm{CMC}$ at room temperature. At time intervals $10 \mu 1$ of incubation mixture was loaded on top of the gel. The current was $3 \mathrm{~mA}$ per gel. The gels were stained with $1 \%$ Amide black $10 \mathrm{~B}$.

Migration was downward toward the anode. Control; native enzyme, $\rightarrow$; top of the gels.

neutralization of negative charge of enzyme by the modification of carboxyl radicals or others with $\mathrm{CMC}$ or aggregation of enzyme molecules caused by CMC treatment.

2. Activity yield of immobilized glucose isomerase

The effects of CMC concentration and reaction time on the activity yield of immobilized glucose isomerase are shown in Figs. 3 and 4.

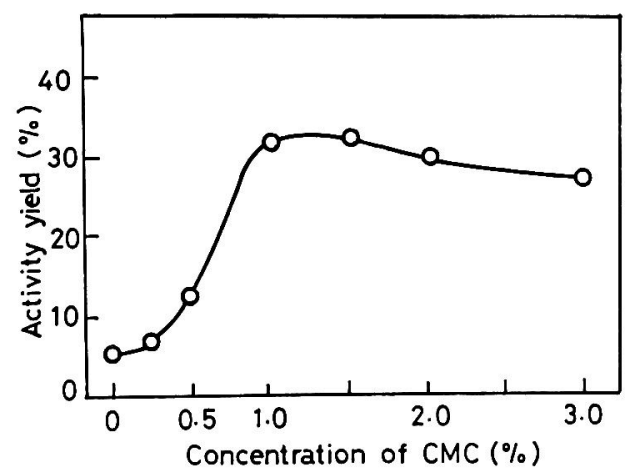

FIG. 3. Effect of CMC Concentration on Binding of Glucose Isomerase to Chitosan.

Binding reaction was continued for $5 \mathrm{hr}$. The activity yield was expressed as a percent of immobilized activity to added activity. 


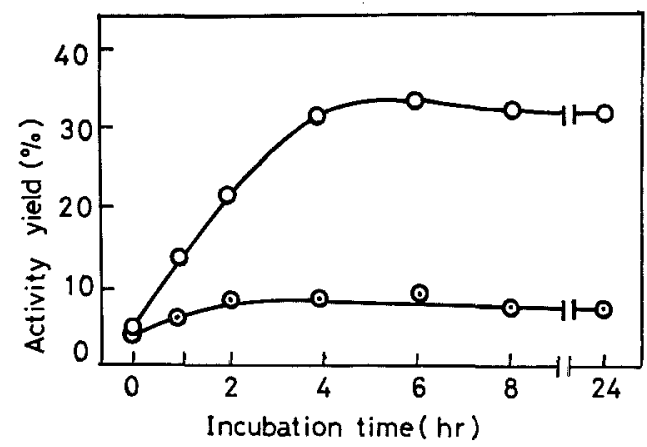

FIG. 4. Time Course of Binding Reaction of Glucose Isomerase to Chitosan.

Basal composition of incubation mixture was $25 \mathrm{ml}$ of chitosan solution and $5 \mathrm{ml}$ of enzyme. At time intervals, $3 \mathrm{ml}$ of mixture was taken into a small tube and immobilized enzyme was precipitated with an ammonium buffer.

$\mathrm{O}-\mathrm{O} \mathrm{CMC}$ added to the reaction mixture was $1 \%$ $(300 \mathrm{mg})$ in a final concentration, $\odot-\odot$ without addition of $\mathrm{CMC}$

Maximal activity was given in the treatment with ca. $1 \% \mathrm{CMC}$ for $4 \sim 5 \mathrm{hr}$ reaction, and with CMC over $1 \%$ concentration a little decrease in activity was observed. Chitosan mixed with the enzyme solution without the addition of CMC showed some activity. Therefore it seemed that a small portion of the immobilized enzyme might be bound to the carrier with simple adsorption. Activity yield of chitosan bound glucose isomerase was found to be $26 \sim 40 \%$ (mean $32 \%$ ) as shown in Table I.

Table I. Activity Yield of Chitosan Bound Glucose IsOMERASE

Binding reaction was carried out with $1 \% \mathrm{CMC}$ for $6 \mathrm{hr}$. Chitosan used as carrier was ca. $25 \mathrm{mg}$ in dry weight.

\begin{tabular}{ccccc}
\hline \multicolumn{2}{c}{ Added activity } & & \multicolumn{2}{c}{ Bound activity } \\
\cline { 1 - 2 } $\begin{array}{c}\text { Protein } \\
\text { (mg) }\end{array}$ & Unit & & Unit & $\begin{array}{c}\text { Yield } \\
(\%)\end{array}$ \\
\hline 0.62 & 37.4 & & 12.0 & 32.1 \\
0.72 & 43.4 & & 17.5 & 40.3 \\
1.27 & 76.5 & & 20.4 & 26.7 \\
1.69 & 102.0 & & 36.2 & 35.5 \\
1.69 & 102.0 & & 29.8 & 29.2 \\
1.69 & 102.0 & & 32.4 & 31.8 \\
2.54 & 153.0 & & 41.6 & 27.2 \\
& & Mean & $(31.8)$ \\
\hline
\end{tabular}

When solid chitosan was employed as insoluble carrier the yield of immobilized enzyme was only $8 \sim 13 \%$. The fact provided the evidence that coupling reaction was hard to proceed in a multiphase reaction.

\section{Effect of temperature on the enzyme reac- tion}

Effect of temperature on the activity of free and immobilized glucose isomerase was examined. Both enzymes showed similar profiles. The maximal activities were obtained at $80^{\circ} \mathrm{C}$ with both enzymes.

\section{Heat stability}

Heat stability of enzyme was investigated. No significant change was observed by immobilization, being different from the case of glucose isomerase entrapped in polyacrylamide gel ${ }^{11}{ }^{11}$ which was considerably fortified in heat stability. Addition of $1 \mathrm{~mm}$ of cobaltous ion was effective in increase of heat stabilities of free and immobilized enzyme to the same extent.

\section{Effect of $\mathrm{pH}$}

The $\mathrm{pH}$ dependence of reaction was investigated. A slight shift of $\mathrm{pH}$ optimum to acid

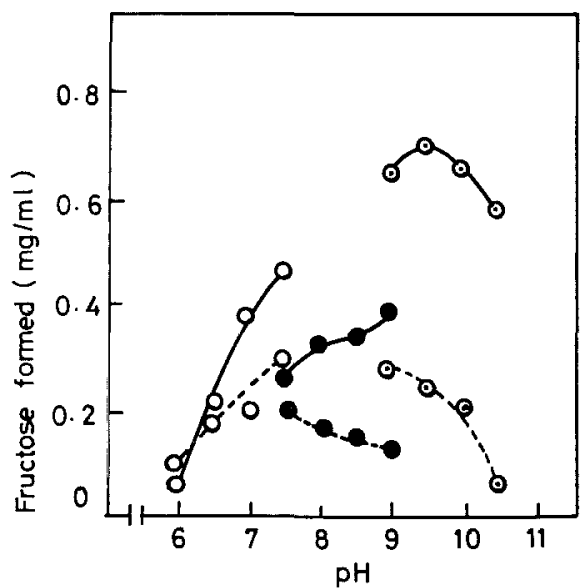

FIG. 5. Effect of $\mathrm{pH}$ on the Activity of Glucose Isomerase.

Final concentration of each buffer was $0.05 \mathrm{M}$. $\bigcirc-O$, phosphate, free enzyme; $\bigcirc--\bigcirc$, phosphate, immobilized; - - Tris-HCl, free; -- , Tris- $\mathrm{HCl}$, immobilized; $\odot-\odot$, carbonate, free; $\odot--\odot$, carbonate, immobilized. 


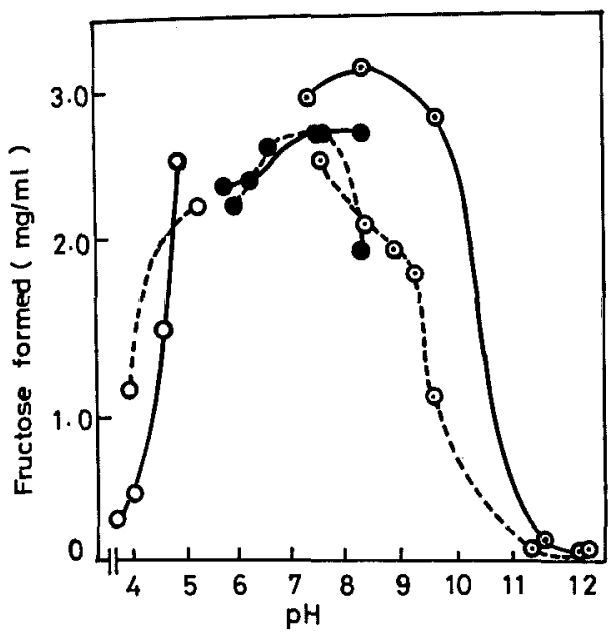

FIG. 6. Profile of pH Stability Range of Glucose Isomerase.

After incubation at various $\mathrm{pH}$ at $30^{\circ} \mathrm{C}$ overnight, remaining activity was estimated.

$0-0$, acetate, free enzyme; $\mathrm{O}--\mathrm{O}$, acetate, immobilized; - - , Tris-maleate, free; $---\bullet$, Tris-maleate, immobilized; $\odot-\odot$, glycine-NaOH; free; $\odot--\odot$, glycine- $\mathrm{NaOH}$, immobilized.

side was observed as the result of immobilization. As shown in Fig. 5, an optimal pH was found to be $9 \sim 9.5$ for free enzyme, while pH 8 8.5 was optimum for immobilized enzyme. Figure 6 showed the result of $\mathrm{pH}$ stability of glucose isomerase. After incubation at various $\mathrm{pH}$ at $30^{\circ} \mathrm{C}$ overnight, remaining activity was estimated. The $\mathrm{pH}$ range in which the enzyme was stable was also shifted to acid side. These changes caused by immobilization were supposed to be due to the characteristics of the carrier, chitosan. Positive charge of chitosan surrounding the enzyme might give some influences on the enzyme characteristics as polyelectrolyte.

\section{Effect of bivalent metal ions}

Enzyme activity was determined in the reaction mixture containing various metal ions. The results are shown in Table II. Free glucose isomerase was inhibited by metal ions such as $\mathrm{Ca}^{2+}, \mathrm{Ni}^{2+}, \mathrm{Mn}^{2+}, \mathrm{Cu}^{2+}, \mathrm{Cd}^{2+}$ but inhibition was considerably relieved by immobilization. The reason is not clear, but it might be due to the chelating activity of
Table II. Effect of Metal Ions on the ACTIVITY of Glucose Isomerase

\begin{tabular}{crc}
\hline \multirow{2}{*}{ Metals } & \multicolumn{2}{c}{ Relative activity $(\%)$} \\
\cline { 2 - 3 } & Free & Immobilized \\
\hline None & 100 & 100 \\
$\mathrm{Ca}^{2+}$ & 29 & 49 \\
$\mathrm{Sr}^{2+}$ & 86 & 82 \\
$\mathrm{Ba}^{2+}$ & 107 & 106 \\
$\mathrm{Ni}^{2+}$ & 24 & 61 \\
$\mathrm{Mn}^{2+}$ & 11 & 44 \\
$\mathrm{Cu}^{2+}$ & 3 & 57 \\
$\mathrm{Cd}^{2+}$ & 3 & 28 \\
$\mathrm{Zn}^{2+}$ & 3 & 19 \\
$\mathrm{Co}^{2+}$ & 105 & 107 \\
\hline
\end{tabular}

Various metal ions were added to the reaction mixture $\left(0.8 \mathrm{M}\right.$ glucose, $0.01 \mathrm{M} \mathrm{MgSO}_{4}, 0.05 \mathrm{M} \mathrm{pH} 7.5$ phosphate buffer and enzyme) to be $1 \times 10^{-3} \mathrm{M}$ in a final concentration.

chitosan for various metal ions. ${ }^{221}$

\section{Effect of buffer reagents and denaturants}

The activity of free glucose isomerase was inhibited by buffer reagents such as Tris or veronal. In the reaction with these buffers, only about a half activity was determined comparing with the activity in phosphate buffer. As shown in Table III, however, inhibition was mitigated by immobilization.

Table III. EFfects of Buffer Reagents AND Denaturants on the Activity of Glucose ISOMERASE

\begin{tabular}{lrc}
\hline & \multicolumn{2}{c}{ Relative activity $(\%)$} \\
\hline Buffers $^{a)}$ & Free & Immobilized \\
Phosphate & & \\
Tris-HCl & 100 & 100 \\
Veronal & 46 & 67 \\
Denaturants ${ }^{b)}$ & 55 & 102 \\
None & 100 & 100 \\
$8 \mathrm{M}$ Urea & 61 & 65 \\
$6 \mathrm{M}$ Gu·HCl & 0 & 0 \\
$1 \%$ SDS & 94 & 23 \\
$10^{-1} \mathrm{M}$ Cysteine & 92 & 40 \\
$2 \%$ Mercaptoethanol & 96 & 61 \\
\hline
\end{tabular}

a) Concentrations of three kinds of buffer were $0.05 \mathrm{M}$ and $\mathrm{pH}$ values all 7.5 .

b) After incubation with various denaturants for $2 \mathrm{hr}$ at $40^{\circ} \mathrm{C}$, enzyme activity was estimated in the reaction mixture containing the same concentration of denaturants. 
Especially in veronal buffer immobilized enzyme showed nearly the same activity as in phosphate buffer.

Effects of denaturants are also shown in Table III. In the presence of $8 \mathrm{M}$ urea or $6 \mathrm{M}$ guanidine hydrochloride free and immobilized glucose isomerase were inhibited rather strongly in a similar way. But with $1 \%$ SDS, $10^{-1} \mathrm{M}$ cysteine or $0.5 \mathrm{M}$ 2-mercaptoethanol two enzymes were affected in some different way. Though free enzyme was scarcely attacked by these reagents, immobilized enzyme was considerably suffered to a loss of its activity.

\section{Continuous reaction}

Continuous isomerization of glucose was carried out using $1.9 \mathrm{~cm}$ dia. $\times 40 \mathrm{~cm}$ column packed with the chitosan-glucose isomerase. The result is shown in Fig. 7. After 5 days operation, the isomerizing power of the column went down to $60 \%$ of the beginning value and thereafter it continued without significant drop in activity over 20 days. Interestingly, $\mathrm{pH}$ of the product was maintained at about 7 , nevertheless substrate solution used did not contain any buffer.

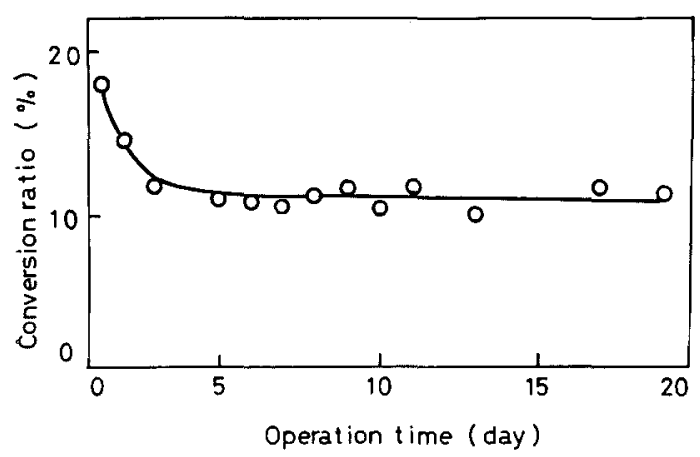

FIG. 7. Continuous Isomerization of Glucose.

Substrate solution ( $0.8 \mathrm{M}$ glucose and $0.01 \mathrm{M} \mathrm{MgSO}_{4}$ ) was adjusted $\mathrm{pH} 9.0$ with dil. $\mathrm{NaOH}$ before use and space velocity of reaction was 0.12 .

\section{Activity yield of other enzymes}

Results of coupling are shown in Table IV. Yield was expressed as the percent of immobilized activity to the added activity. As for
Table IV. Activity Yield of Chitosan BOUND ENZYMES

\begin{tabular}{lrrrr}
\hline \multirow{2}{*}{ Enzymes } & Added activity & & \multicolumn{2}{c}{ Bound activity } \\
\cline { 2 - 2 } \cline { 5 - 6 } & Unit & & Unit & $\begin{array}{c}\text { Yield } \\
(\%)\end{array}$ \\
\hline Urease & 1.316 & & 0.580 & 44.1 \\
Glucamylase & 448 & & 33 & 8.0 \\
Trypsin & 307 & & 32 & 10.4 \\
Glucose oxidase & 51 & & 19 & 37.3 \\
\hline
\end{tabular}

urease and glucose oxidase, rather higher yields than glucose isomerase were obtained, while trypsin and glucamylase gave lower yields.

\section{DISCUSSION}

Carrier for immobilization of enzyme should be excellent in preservation of enzyme activity, solidity and durability, and also less expensive, non toxic especially for food processing. From these point of view, we chose a chitosan as an insoluble carrier. Chitosan is prepared through deacetylation of chitin which is distributed widely in the nature and most of it has been left as an unutilizable waste.

In covalent binding method, it has been tried to introduce various functional groups to natural and synthetic polymers as carrier for example, porous glass beads, acrylic copolymer, CNBr-Sephadex or Sepharose, CMcellulose, dialdehyde starch etc. Conveniently, chitosan contains originally many amino radicals derived from glucosamines, constituent of it. In dissolved state these amino radicals seem to serve effectively as ligand in binding reaction with enzyme in the presence of water soluble carbodiimide. Chitosan-enzyme complex is easily solidified by adjustment of $\mathrm{pH}$ from acidic to alkaline.

According to Khorana, ${ }^{23)}$ water soluble carbodiimide first reacts upon the carboxyl group to form $\mathrm{O}$-acyl isourea as intermediate and successively this intermediate reacts with amine if it is present in the reaction system to produce an amide. Water soluble carbodiimide may also react with a cysteine or a tyrosine residue of enzyme protein, though these complexes are 
fairly stable under neutral and acidic conditions. ${ }^{24,26)}$ So it is assumed that the formation of covalent bonds between amino groups of chitosan and carboxyl groups of enzyme take place in immobilization of enzymes. And other binding between amino groups of chitosan and sulfhydryl or hydroxyl groups of enzyme might be created.

Glucose isomerase was partially inactivated by the treatment with carbodiimide in the absence of amine, but it did not in the presence of excess mole of D-glucosamine. Accordingly this inactivation may be due to the steric hindrance induced by intra- or intermolecular reaction between amino and carboxyl or other groups of enzyme protein, as Sheehan et al. ${ }^{26)}$ pointed out. The yield of activity of immobilized glucose isomerase gradually increased as the reaction proceeded, but it remained around $30 \%$. The presumption concerning with factors which may affect on the activity yield is that carboxyl or other radicals taking part in the reaction are restricted just on a surface of native enzyme though amino radicals exist enough, the length of spacer ( $\mathrm{C}-\mathrm{N}$ bond) is not sufficient to avoid a steric hindrance, $\mathrm{pH}$ value of reaction may not be optimal (Actually $\mathrm{pH}$ is limited to about 6 according to both properties of glucose isomerase and chitosan solution, despite of the optimal $\mathrm{pH}$ range for $\mathrm{CMC}$ reaction to protein is estimated to be $4.5 \sim$ 5.0.). ${ }^{27)}$

It is probable that the electrostatic property of enzyme is changed by the positive charge of the chitosan. The shift down of $\mathrm{pH}$ optimum and $\mathrm{pH}$ stability range can be explained by this effect. The similar phenomena are shown in previous papers for example, DEAE-celluloseaminoacylase, ${ }^{28)}$ DEAE-Sephadex-aminoacylase, $\left.{ }^{29}\right)$ DEAE-cellulose-invertase, ${ }^{30)}$ DEAEcellulose-ATP deaminase ${ }^{31}$ etc. Inhibitory effect of negative charged reagents such as SDS, 2-mercaptoethanol and cysteine stimulated by immobilization may also come from the charge effect.

Chitosan-enzyme complex is unfavourably liquefied again in acid solution. To avoid this it would be a way to block free amino groups of chitosan by such a method as acetylation, taking care not to result in a loss of activity of immobilized enzyme.

\section{REFERENCES}

1) E. Katchalski, I. Silman and R. Goldstein, "Advances in Enzymology," Vol. 34, ed. by F. F. Nord, Interscience Publishers, 1971.

2) O. R. Zaborsky, "Immobilized Enzymes," CRC Press Inc., 1972.

3) S. T. Gutcho, "Immobilized Enzymes, Preparation and Engineering Techniques," Noyes Data Corporation, 1974.

4) N. Tsumura and M. Ishikawa, Nippon Shokuhinkôgyô Gakkaishi, 14, 6 (1967).

5) G. W. Strandberg and K. L. Smiley, Appl. Microbiol., 21, 588 (1971).

6) G. W. Strandberg and K. L. Smiley, Biotechnol. Bioeng., 14, 509 (1972).

7) S. Giovenco, F. Morisi and P. Pansolli, FEBS Lett., 36, 57 (1973).

8) S. Amotz, T. K. Nielsen and N. O. Thiesen, U. S. Patent, 501292 (1975).

9) Y. Yokote, K. Kimura and H. Samejima, Die Stärke, 27, 302 (1975).

10) R. A. Messing and A. M. Fillbert, J. Agric, Food Chem., 23, 920 (1975).

11) T. Kasumi, K. Kawashima and N. Tsumura, J. Ferment. Technol., 52, 321 (1974).

12) T. Kasumi, M. Tsuji and N. Tsumura, Rept. Natl. Food Res. Inst., 30, 54 (1975).

13) N. Tsumura, T. Kasumi and M. Ishikawa, ibid., 31, 71 (1976).

14) N. Tsumura and T. Kasumi, Immobilization of Glucose Isomerase in Microbial Cell, 5th International Fermentation Symposium, Berlin, 291 (1976).

15) N. Tsumura and T. Sato, Agric. Biol. Chem., 29, 1129 (1965).

16) Z. Dische and E. Borenfreunt, J. Biol. Chem., 192, 583 (1951).

17) D. D. Van Slyke and R. M. Archibald, ibid, 154, 623 (1944).

18) H. Okazaki, Nippon Nôgeikagaku Kaishi, 29, 605 (1955).

19) M. Somogyi, J. Biol. Chem., 195, 19 (1952).

20) B. Hagihara, Ann. Rep. Sci. Works, Osaka Univ., 2, 35 (1954).

21) O. Folin and V. Ciocalteu, J. Biol. Chem., 73, 629 (1927).

22) T. Koshijima, R. Tanaka, E. Muraki, A. Yamada and F. Yaku, Cellulose Chem. Technol., 7, 197 (1973).

23) H. G. Khorana, Chem. Rev., 53, 145 (1953).

24) K. L. Carraway and D. E. Koshland, Biochim. 
Biophys. Acta, 160, 272 (1968).

25) K. L. Carraway and R. B. Triplett, ibid., 200, 564 (1970).

26) J. C. Sheehan and J. J. Hlavka, J. Am. Chem. Soc., 79, 4528 (1957).

27) G. E. Means and R. E. Feeney, "Chemical Modification of Proteins," Holden-Day, Inc., 1971.

28) T. Tosa, T. Mori, N. Fuse and I. Chibata,
Enzymologia, 32, 153 (1967).

29) T. Tosa, T. Mori and I. Chibata, Agric. Biol. Chem., 33, 1053 (1969).

30) H. Suzuki, Y. Ozawa and H. Maeda, ibid., 30, 807 (1966).

31) S. T. Chung, M. Hamano, K. Aida and T. Uemura, ibid., 32, 1287 (1968). 